\title{
Representations of Catholicism in Contemporary Spanish Anarchist-themed Film (1995-2011)
}

\author{
Pedro García-Guirao
}

King's College London

This essay explores the portrayal of Catholicism in eight Spanish anarchist-themed films. The first part discusses negative representations of the Catholic religion rehearsed in these films, set as they are mainly in the context of the Spanish Civil War. Among those representations are: the political and economic purpose of the Catholic Church's control of education in Spain; the breaking of the religious vows of poverty and chastity, and the recourse to praising the vow of obedience when under scrutiny; and the breaking of the seal of the confessional. In the second part, the essay shows that those films also portray a Christianity which can be more solidary, revolutionary and attached to a different idealization of Christ, unlike the Church consisting of high-ranking members of the clergy. This second part also considers the notion of "secularization" and the extent to which anarchism has become an alternative religion in these films. The essay also reflects on the reliability of films as historical sources.

Like any work of history, a film must be judged in terms of the knowledge of the past that we already possess. Like any work of history, it must situate itself within a body of other works, the ongoing (multimedia) debate over the importance of events and the meaning of the past. ${ }^{\mathrm{I}}$

Almost coinciding with the $60^{\text {th }}$ anniversary of the outbreak of the Spanish Civil War, two respectively anarcho-communist (and

I Robert Rosentone, 'The historical film as real history', Film-historia online, I (I995), 5-23 (p. 9).

How to cite this book chapter:

García-Guirao, P. 2018. Representations of Catholicism in Contemporary Spanish Anarchist-themed Film (I995-20II). In: Christoyannopoulos, A. and Adams, M. S. (eds.) Essays in Anarchism and Religion: Volume II. Pp. 94-I 3 I. Stockholm: Stockholm University Press. DOI: https:/doi.org/Io.I6993/bas.d. License: CC-BY. 
anarchist or libertarian)-themed blockbusters were released: Land and Freedom (1995) and Libertarias (1996). These films relay the view that for Franco the armed conflict was in large part a religious issue: a crusade against atheists, communists, Jews and Freemasons. ${ }^{2}$ After all, the central role of the Catholic Church in the conflict was illustrated by the radio message sent by Pope Pius XII "To the faithful of Spain" on I4 April I939 in which he expressed support for Franco and blessed the Christian heroism of those who had defeated the impious red forces. ${ }^{3}$ The films touch on that support, but they also document the anticlerical wave that emerged among certain anarchist, republican and communist groups during the Second Spanish Republic (I93 I-I939) and notably during the Spanish Civil War (I936-I939).4

2 "[...] The Spanish war was not a political conflict or a class struggle, but rather a war of two civilizations - a Catholic one and an alien, anti-Spanish, and Marxist one. According to Pla y Deniel [a Spanish bishop], the war resulted from the apostasy of the nation (the Bishop could not conceal the fact that most Spaniards supported the Republic), civil marriages, and the secular education system". In: Tadeusz Miłkowski, 'The Spanish Church and the Vatican during the Spanish Civil War', The Polish Foreign Affairs Digest, 3 (2004), 207-242 (p. 208).

3 "With great joy We address you, most dear children of Catholic Spain, to express to you our fatherly congratulations for the gift of peace and of victory, with which God has deemed worthy to crown the Christian heroism of your faith and charity, tried in so many and so generous sufferings. Our Predecessor, of venerable memory, expected, with longing and trust, this Providential peace, which is undoubtedly the fruit of that copious blessing which he sent, in the very beginning of the struggle, 'to all those who had devoted themselves to the difficult and dangerous task of defending and restoring the rights and the honour of God and Religion'; and We do not doubt that this peace shall be the one that he himself foretold since then, 'the sign of a future of tranquillity in order, and of honour in prosperity". Cited in Mundabor, 'Pope Pius XII's Message After the Victory In Spain. I4 April I939'. <http://mundabor.wordpress.com/20II/o7/2I/ pope-pius-xiis-message-after-the-victory-in-spain/> [accessed 26 July 20I 2 ]. See Mary Vincent, Catholicism in the Second Spanish Republic: religion and politics in Salamanca, I930-1936 (Oxford: Clarendon Press, I996).

4 Two good sources on Spanish anticlericalism are: Manuel Pérez Ledesma, 'Studies on Anticlericalism in Contemporary Spain', International Review of Social History, 46 (200I), 227-255; and Julio Caro Baroja, Introducción a una historia contemporánea del anticlericalismo español (Madrid: ISTMO, I980). 
These films, however, have a tendency to rehearse old stereotypes corrupted by the violent excesses of the Spanish Civil War - "the war that won't die".5 For example, in Land and Freedom (I995) and Libertarias (I996) anarchists continue to be "condemned as apostles of violence" 6 while the clergy are represented as apostles of fascism. Despite this, however, they also hint at a revised conception of religion whereby the real enemy is shown to be the ecclesiastical hierarchy, not necessarily all of the clergy, or all aspects of Christian ethics. The aim of this essay, therefore, is to provide a panoramic overview of Catholicism as portrayed in Spanish film productions that could be qualified as "anarchist-themed", first by considering the recurrence of old anticlerical sentiments, then by looking at the aspects of religion which are portrayed as implicitly more redeemable.

It should be clear that the contemporary Spanish anarchist-themed films analysed here do not belong to what might be termed propaganda film. ${ }^{7}$ In what follows, “anarchist cinema” (or anarchistthemed cinema) is defined according to Stuart Christie's criteria as "not necessarily films made and produced by anarchists - some of which can be very boring indeed", but as also including "several anti-authoritarian films made by non-anarchists". ${ }^{8}$ I will also follow the canon in approaching the "Spanishness" of those films relatively broadly, given that at present the transnational nature of Spanish film seems unquestionable: "To talk of Spanish cinema is to talk of its relations with other cinemas, through coproductions, through the sharing of actors and technical personnel, and

5 I have borrowed this expression from: David Archibald, The War That Won't Die: The Spanish Civil War in Cinema (Manchester: Manchester University Press, 2013).

${ }^{6}$ Richard Porton, On Anarchist Cinema. Anarchist Film and Video (Oakland-Sussex: PM Press-ChristieBooks, 2009), p.vi.

7 See Magí Crusells Valeta, 'Cinema as a political propaganda during the Spanish Civil War: España I936’, Ebre, 38, (2004), I-I2.

8 Cited in: Porton, On Anarchist Cinema, p. I6. In the same book, Porton (p.i) asked: “If we speak of 'anarchist cinema,' are we referring to films about the historical experience of anarchists and anarchism or films with an anarchist impetus that might have been made by non-anarchists?"”. For a further discussion see: Duncan Campbell, 'A revolution in cinema?', The Guardian, 24 November 2006. <http:/www.theguardian.com/ film $/ 2006 / \mathrm{nov} / 24 / \mathrm{I}>$ [accessed I 5 July 20I3]. 
particularly through its drawing on a common fund of formal, generic, and thematic concerns". ${ }^{9}$ Thus, in addition to Land and Freedom (I995) and Libertarias (I996), I will also analyse $\mathrm{La}$ lengua de las mariposas [Butterfly's Tongue] (1996); Salvador (2006); El corazón de la tierra (2007) also known as The Heart of Earth; Los girasoles ciegos [The Blind Sunflowers] (2008); La mujer del anarquista (2009) or The Anarchist's Wife, directed by the German film director Peter Sehr in collaboration with the French scriptwriter Marie-Noëlle Barré; and El cine libertario: Cuando las peliculas hacen historia [The Libertarian Film: When Films Leave Historical Legacies] (20I I).

Similarly, taking 'anarchism' and 'religion' as umbrella terms is not without its problems. 'Anarchism' alludes here to the historical-philosophical term that was born in parallel to Liberalism and Utopian Socialism. Even if the word has different implications, some of the common characteristics that it invoked, at least in the Spanish context, include the following: “. . . intellectual, political and social emancipation, which implies moral emancipation, and, upon this basis, the free development of a mature and regenerated

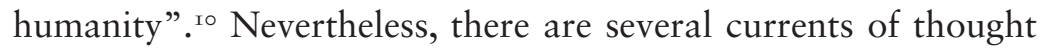
and practice within anarchism that appear in these films: anarcho-communism, anarcho-syndicalism, anarcho-collectivism, anarcho-pacifism, libertarian possibilism or 'possibilistic anarchism', and mutualism, among others. For its part, the term 'religion' seems more unproblematic in this context: in the context of this essay it refers mainly to the Catholic Church (as an institution with a strong hierarchical structure) but also to a set of beliefs (based on the principles from the gospel) held by grassroots Christians.

It is also worth acknowledging at the start the highly conflicting relationship between the "fictional film" genre and its approach to using film-as-history, as suggested by the epigraph above. On this issue, this essay takes film as a valid (but special) form of historical discourse, as a "vital source of information on what people believed" and as "an index to the key problems of a period and even

9 Jo Labanyi, and Tatjana Pavlović, eds, A Companion to Spanish Cinema (Oxford: Wiley-Blackwell, 20I2), p. I.

ro Max Nettlau, A Short History of Anarchism (London: Freedom Press, I996), p. 44 . 


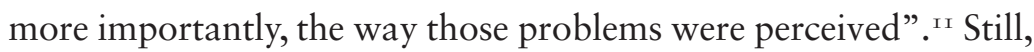
there is a debate condensed in one crucial question: "In what sense does a film reflect the society in which it is made and therefore tell us something about that time and that place that is of value for the historian?" I2 Of these difficulties, three significant issues are worth highlighting.

In the first place, there is the issue of genre. Even though these films are part of a fictional narrative, we could frame them within the genre of "historical film". According to two of the most important internet film databases (IMDb, FilmAffinity), the majority of these films fit into "drama", "history" and "war" (or "post-war") genres. Salvador, for instance, is described as a "drama" and "based on a true story", while El cine libertario: Cuando las películas hacen historia is classified as a "documentary" and "movie documentary". Helpful as that taxonomy is for those databases, film critics agree that categorizing these films is neither straightforward nor unproblematic. ${ }^{\mathrm{I3}}$

The second main difficulty for those working in film studies is the danger of using a film as history or as an historical document. Film academics call "representation [...] the process by which the media presents the real world to an audience". ${ }^{14}$ To present films as history, though, can be controversial: "historians will say, films are inaccurate. They distort the past. They fictionalize, trivialize, and romanticize important people, events, and movements. They falsify History". ${ }^{15}$ Rare, therefore, are the films which represent the past as accurate, historical documents, despite the temptation to present them as such.

i Warren I Susman, 'Film and History: Artefact and Experience', in Hollywood and the American Historical Film, ed. by J.E.Smyth (London: Palgrave Macmillan, 20I I), I-I I (p. 4).

${ }^{12}$ Susman, p. 4 .

${ }^{13}$ See Stephen Schwartz, 'The paradoxes of film and the recovery of historical memory: Vicente Aranda's works on the Spanish Civil War', Film History: An International Journal, 4 (2008), 50I-507, (p. 50I).

${ }^{14}$ Philip Rayner, Peter Wall and Stephen Kruger, AS media studies: the essential introduction. (London: Routledge, 2004), p. 6I.

i5 Rosenstone, p. I. 
The third difficulty, building on the second, concerns the degree to which these films in fact construct and invent "reality" ${ }^{16}$ In that regard, three factors are worth bearing in mind: a) the "ideological positions of directors and screenwriters"; b) the "emotions" they choose to express to "help understand the events they relate to"; and c) the way they sometimes become perceived as "excellent" and alternative "sources of information" to contrast to the received orthodoxy (in other words, the history they represent is actually taken as a narrative to query the established one). ${ }^{17}$

Nonetheless and notwithstanding the risk of simplification, history books are also created in specific contexts: historians write with their ideological agendas shaping the way the past is perceived and facing similar problems of objectivity, even though some would argue that there is at least one fundamental difference between fiction and history, which is that "[. . .] both tell stories, but history tells a true story" ${ }^{18}$ My general assumption in this essay is that fictional Spanish films - understood as cultural products of a symbolic system ${ }^{19}$ - work as sociological indicators of the cosmovision or worldview of the specific society in the specific era in which they were made. ${ }^{20}$ Furthermore, films can even be considered "interpreters of history" ${ }^{21}$ Therefore, in the analysis which follows, where appropriate I will touch on the chosen tone of the films, on the audiences and reception of the films, on the historical context that they purport to represent, and on their construction or propagation of stereotypes.

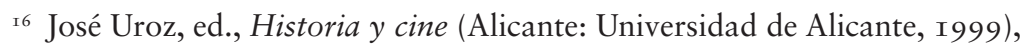
p. 6.

${ }^{17}$ Francisco Javier Zubiaur Carreño, 'El Cine como fuente de la Historia', Memoria y civilización: anuario de historia de la Universidad de Navarra, 8 (2005), 205-2I9 (p. 2I 5). Unless otherwise indicated, all translations from Spanish to English are mine.

I8 Rosenstone, p. 8.

19 Martín Paradelo Núñez, 'El mundo a través de un cristal. Alcance crítico de los modos de representación cinematográficos', Estudios. Revista de Pensamiento Libertario, 2 (20I 2), 76-IOI (p. 78). And, Susman, p. 9.

${ }^{20}$ Labanyi and Pavlović, p. 2. On this topic see: Luise White, 'Telling more: lies, secrets, and history', History and Theory, 4 (2000), I I-22, and Jennifer Jensen Wallach, 'Building a bridge of words: The literary autobiography as historical source material', Biography, 3 (2006), 446-46I.

${ }_{21}$ Susman, p. 5 . 
In what follows, I will first pinpoint and discuss some of the old negative representations about Catholicism which Spanish anarchist-themed films indulge in: first, the traditional role of the Catholic Church as an institution that monopolized education in Spain for several centuries; then the supposed violation of religious vows (vow of poverty, and vow of chastity) and the exaltation of the vow of obedience by churchmen under scrutiny, mainly in the midst of the Spanish Civil War; and then the violation of the seal of the confessional. Secondly, I will argue that despite these negative representations, there was never a homogeneous church in Spain either during the Civil War or during Franco's Regime, and I will show that those films do also portray a Christianity which can be more solidary, revolutionary and attached to a different ideation of Christ, unlike the Church consisting of high-ranking members of the clergy. This second part will also discuss the notion of "secularization" and the degree to which anarchism has become an alternative religion in these films. In the conclusion, I will return to the controversial question of the link between anarchist films and representations of religion, and the extent to which films are good sources of historical information.

\section{Negative representations}

Let us start by listing the old anti-religious sentiments that appear in these films. They are replete with scenes of anticlericalism, and instances of spontaneous violence against Catholic symbols. The films similarly caricature the entire religious class, portraying priests as dogmatic masters of the education system. The Church is represented as an immoral corporation, concealing cases of religious men perpetrating sexual abuse, general criminal activity, and showing a lack of respect for the vow of silence implicit in confession. In short, these anarchist films tend to settle scores with old enemies: if Francoist sympathizers set out to build an image of anarchists focused on fanaticism, intolerance and crime, libertarian-themed film tends to create a similar iconography of the members of religious orders associated with the Francoist side. 


\subsection{The monopoly of education ${ }^{22}$}

One way to understand the roots of this anticlericalism is by looking at the religious monopoly on education in Spain: "Workers not only believed the clergy made a profit from their schools, but considered them an obstacle to the development of a free public school system. [...] Articulate labour spokesmen [.. .] declared that the ideas taught in Catholic schools were antithetical to the cause of workers' rights". ${ }^{23}$ In I 877 , an alarmingly high $72 \%$ of the Spanish population was illiterate. ${ }^{24}$ Thirty-three years later, the illiteracy rate was still high: 59\% among adults and 50\% among children over the age of $10 .{ }^{25}$ These rates of illiteracy can be explained in part by the country's economic poverty, but another reason could also be that education was subject to payment of a fee, and was in the hands of the institution that had been the most ideologically and economically powerful entity in Spain since the I $5^{\text {th }}$ century - that is, the Catholic Church. In other words: only the children of the wealthy could afford to pursue an education. This compounded the workers' misery, and had become a cause of hostility towards the Church: "One major problem was the clergy's need to finance its activities, and the corresponding resentment of workers who had to pay for the services or who simply disliked the money-making activities of a religious institution". ${ }^{26}$ The long-term legacy of these injustices can be seen in both $\mathrm{La}$ lengua de las mariposas and Los girasoles ciegos.

${ }^{22}$ For a deeper analysis on anarchism and education in Spain see Carolyn P. Boyd, 'The Anarchists and Education in Spain, I 868-1909', The Journal of Modern History, 48.4 (I976), I 25-I70. And Pedro García-Guirao, 'Francisco Ferrer y las misiones pedagógicas del anarquismo español' (Murcia: Biblioteca Saavedra Fajardo, 2007).

${ }^{3}$ Joan Connelly Ullman, The tragic week: a study of anticlericalism in Spain, I875-I9I2 (Cambridge: Harvard University Press, I968), pp. 326-327.

${ }_{24}$ Compared to other countries in 1870 , illiteracy rates were $68 \%$ in Italy (a strongly Catholic country), 24\% in Great Britain and $31 \%$ in France. <http://ourworldindata.org/data/education-knowledge/literacy/> [accessed Io June 2015].

${ }_{25}$ M. Gloria Espigado Tocino, 'El analfabetismo en España. Un estudio a través del censo de población de I 877', Trocadero: Revista de historia moderna y contemporanea (I990), I73-I92.

${ }^{26}$ Joan Connelly Ullman, p. 326. 
The first of these, La lengua de las mariposas, centres on the relationship between a pupil (Moncho) and his schoolteacher (Don Gregorio) a few months before Francisco Franco's coup in July I936. Moncho does not want to go to school because everyone has told him that all religious teachers beat their pupils. However, Don Gregorio turns out not to be like those feared religious teachers. He is a freethinker (an anarchist) and a "kindly if unorthodox" ${ }^{27}$ educator who believes not in God, but in what he calls the "Observation Method" - a scientific method based on empirical observation and measurable data - and he opposes the repressive methods of clerical teachers committed to using fear and punishment. Don Gregorio - as theorised by Francisco Ferrer, the founder of the Escuela Moderna or Modern School ${ }^{28}$ conceives of the classroom as a laboratory to change mentalities and as a permanent experiment based on observation and on Maieutic pedagogical methods rather than on authoritarianism and faith. ${ }^{29}$ Moncho is captivated by his new teacher and friend, but his educational system does not please everyone. For example, the priest complains to Don Gregorio that ever since Moncho started his schooling he no longer cares about going to church and no longer wants to be an altar boy. Don Gregorio interrupts the conversation to say that he does not teach his students to hate the Church but to be free spirits: "Freedom encourages the spirit of

27 Nina Caplan, 'Butterfly's Tongue', Daily Mail, I4 November 2000. <http://www.dailymail.co.uk/tvshowbiz/article-635 I/Butterflys-Tongue. html> [accessed Io January 20I3].

${ }_{28}$ Most of the anarchist educational projects were based on the Modern School. The Modern School was a progressive school founded in I909 by the Catalan libertarian Francisco Ferrer i Guardia. Its principles were free secular education, massive literacy (especially among working class), mixed education, and the abolition of corporal punishments. See Geoffrey C.Fidler,'The Escuela Moderna Movement of Francisco Ferrer: 'Por la Verdad y la Justicia”, History of Educations Quarterly 25 (I985), IO3-I 32.

29 "Considering the hostility of the Church against this conception of the classroom as a laboratory for change, then it is not surprising that Spanish authorities had received with concerns Ferrer's proclamation [. . . ] that 'the child, in order to avoid errors', must be taught that it is 'essential' 'not to admit anything on faith'”. In: Porton, Cine y Anarquismo, p. 195 . 
strong men" (I9:05). To be a free spirit means eliminating dogmas and symbolical chains; and Don Gregorio tries to eliminate these from his pupils' brains. Moncho, the little boy, is intimidated by the idea of Hell. However, Don Gregorio tells him that Hell does not exist, or at least it does not exist in the hereafter but rather on earth itself. Instead he says: "Hate, cruelty, that is hell. Sometimes hell is our very selves" (53:23). In fact, he will suffer what could be considered "hell on earth" in the final scenes of the film, when Moncho's mother (and the wife of a former anarchist) feels compelled to join a public street condemnation of left-wingers shouting: "Criminals, atheists, reds! Atheists, atheists, atheists!" (OI:25:03). Even the former anarchist publicly insults the teacher in order to avoid suspicions falling upon him: "Murderer, anarchist, son of a bitch, bastard, atheist, atheist, atheist" (OI:27:00).

For some film critics La lengua de las mariposas is a clear example of "sugar-coated history", fictional, invented, or untrue, and devoid of any historical value. It is:

Republican Spain seen through rose-tinted glasses; a harsh and bitter world, magically transformed into an idyllic premodern utopia about to be cruelly crushed by fascism. There is a refusal to engage with a concrete historical past, and what is presented [. . .] is a nostalgic recreation of a republican Spain that never was. ${ }^{3 \circ}$

In the light of this criticism, the film critic Jesús Miguel Sáez complained about the leftist prejudices advanced in this type of film, made by directors that formed "The cultural humus of PM Zapatero's regime”. ${ }^{\text {I }}$ For Jesús Miguel Sáez, given these ideological conditions, Cuerda's film did not convey any historical learning but a pure intolerance and manipulation of religious issues: "With these kind of films [certain film directors] have been devoted to the 'official historical memory', one that makes the Civil War a clash between the good - defenders of freedom, - and evil - promoters of obscurantism and crime, - and the Church has

30 David Archibald, 'The war that won't die', The Guardian, 28 July 2000. <http://www.guardian.co.uk/film/2000/jul/2 8/culture.features I > [accessed 9 January 2013].

3 Jesús Miguel Sáez González, 'Reseñas de cine', Vivat Academia, I 2 (2008), I-9 (p. 6). 
been included in this latter side". ${ }^{32}$ Regardless of the correctness of this review, his words highlight some of the factors noted in my introduction, such as the importance of film contexts, production and history, as well as the traditional left-wing bias against the Church, not just during the Civil War but also today.

A good example of the representation of the clergy as "promoters of obscurantism and crime" can be found in the role of Don Salvador in Los girasoles ciegos, the polar opposite of Don Gregorio in La lengua de las mariposas. Los girasoles ciegos describes the terrible secret of an apparent widow (Elena) and her son (Lorenzo). Everyone in Orense (Galicia) believes that Elena's husband (Ricardo) died at the beginning of the Civil War (I936) in the Republican faction. In reality, Ricardo lives hidden in a small secret room in their family house, translating freethinking, republican and anarchist authors. Don Salvador, a priest who fought on the fascist side, starts a new job in Orense. He becomes Lorenzo's new teacher. The child is not willing to follow Don Salvador's religious teaching and the priest uses this rebelliousness to approach Elena sexually.

At school the children and the teacher are required to sing the fascist song "Cara al Sol" [Facing the Sun]. Not performing this duty involved serious punishment for the children and their families. Furthermore, in the classroom we can see the three compulsory symbols on display in every Spanish public school: The Crucified Christ, a picture of Franco and another of José Antonio Primo de Rivera. The priest's teaching is based on the following principle: "What matters most at the end of the day is to develop as a good person, in other words as Christians and Spaniards" ( $16: 50$ ). His words mix politics with religion and assume that in order to be a good Spaniard, one has to be a good Christian. Don Salvador's pupils - especially those with Republican relatives return home terrified by the horrendous stories about non-believers told by their teacher.

In La lengua de las mariposas Moncho's mother is afraid of her son's questions regarding his father's Republican ideology. In one scene of this film, he innocently points out to her: "Dad does not

32 Sáez González, p. 4. 
even give a shit about God" ( $16: 20$ ), to which she replies: "Well, that is a sin but Dad believes in God like every upstanding citizen" (16:29). In Los girasoles ciegos, young Lorenzo does not want to sing "Cara al Sol", and he is constantly interrogated by Don Salvador, who is eager to discover what might be going on in his home and the political background of Lorenzo's family, in order to report it to the authorities. In these scenes, both films denounce the sovereign "Right of Death and the Power over Life" that the priests had over the population. Don Salvador not only controls the physical punishment of boys but also, to use a Foucauldian expression, "governs theirs souls". ${ }^{33}$ As film critics have pointed out, the director of the film, Cuerda - who is not necessarily an anarchist, but is a left-wing film director - falls back on the trope of presenting this dark side of the Spanish Church: "[Cuerda] has given more minutes, or at least more kick to the conservative camp of history, that is, to the sphere of the church. Not so much to the faithful people but to the people who see everything from the podium". ${ }^{34} \mathrm{~A}$ distinction is thus drawn between the clergy and the laity, though as we will see later, some films also differentiate between a particularly reactionary church hierarchy and the lower clergy.

\subsection{Caricature and criticism of religious double standards}

This section draws on the film representation of the three vows that Catholic priests have to make to become ordained: poverty, obedience and chastity. According to ecclesiastical law, the clergy must live and act in accordance with these rules. However, the films under analysis portray systematic violations of these vows. This negative and archetypal representation is a pattern within anticlerical Spanish anarchist art and literature: "Priests are

${ }_{33}$ Michel Foucault, 'Right of Death and Power over Life', in The History of Sexuality. Vol. I. An Introduction (Harmondsworth: Penguin Books, I 990), I 33 -I 59.

34 Olmo, ‘Crítica de la película Los girasoles ciegos', (Precríticas, 3 October 2008). <http://www.precriticas.com/criticas/la-lengua-de-los-girasoles/> [accessed Io January 20I3]. 
considered as fanatics, obscurantists and corrupt men, traitors to the Gospel". ${ }^{35}$

\subsubsection{Vow of poverty}

Libertarias focuses on María's story. She is a young nun who is recruited (by force) by Pilar (an anarchist woman) at the beginning of the Spanish Civil War. Their plan is to create a women's group to fight Francoist troops. Very soon, they discover that they have to fight not only Franco but also the macho attitudes of their male anarchist comrades. María doubts her faith in churchmen when she witnesses the ravages of war first hand together with the hidden pesetas of the Church. In Aranda's film, militia members discover sixteen million pesetas in cash and abundant quantities of gold in the Episcopal Palace. They decide to display these treasures publicly so that the people can witness the hypocrisy of the Church while the proletariat starves to death. As Ullman explains, this panders to popular perceptions at the time: "These orders were considered exceptionally wealthy, an opinion based largely on the fact that nuns performed no remunerated service" ${ }^{36}$ This is also an illustration of a classic left-wing criticism of the Church, most famously articulated amongst anarchists by Bakunin in God and the State. He stated that "Christianity is the religion par excellence, because it exhibits and manifests, to the fullest extent, the very nature and essence of every religious system, which is the impoverishment, enslavement, and annibilation of humanity for the benefit of divinity". ${ }^{37}$ In Libertarias, the clergy are portrayed as not even pursuing "the benefit of divinity" but only their own riches. Furthermore, in the middle of a revolutionary anarchist fury aimed at seeking social justice (both in film and reality), the discovery of such a treasure was always likely to entail: firstly, the immediate confiscation of the wealth and property of the church; secondly, the punishment of such a robbery in the name of God;

\footnotetext{
35 Lily Litvak, El cuento anarquista: I 880-I9 I I: antología (Madrid: Fundación Anselmo Lorenzo, 2003), p. 32.

${ }^{36}$ Joan Connelly Ullman, p. 327.

37 Mikhail Bakunin, God and the State (New York: Cosimo Classics, 2008), p. 24 [italics in the original].
} 
and finally, the restitution of this wealth to those who really need it: the people..$^{8}$ Similarly, popular uprisings are represented in these films as a form of historical revenge by the dispossessed against the wealthy elites and as a justification of violence, and especially as an excuse to search religious buildings and churches. In the same way, swift executions are explained and justified by the sheer thrust of popular uprisings. In the context of "revolutionary justice" the image that anarchists hold of the Church was considerably influenced by the actions of its hierarchy: while the priests are often given the benefit of the doubt, those in the upper echelons of the Church's hierarchy are deemed guilty of collaborating with the Franco regime and accused of plundering the working class. ${ }^{39}$ This tells us much about how the Church was perceived not only retrospectively but also today as an accomplice of the oppressive class..$^{\circ}$

\subsubsection{Vow of obedience}

Another negative representation of Catholicism in anarchist-themed films is the portrayal of the vow of obedience to God and the Church as a way of renouncing personal freedom in order to obey blindly the preferences of bishops and popes, often against the principles of the Bible. Conceived in such a way, churchmen were, for anarchist militants, potential traitors of the social revolution which one would expect followers of Jesus to support. For example, the documentary film El cine libertario:

$3^{8}$ "These economic factors formed the basis for the workers' conviction that religious orders and great capitalists were closely linked, and for the popular identification of clericalism with capitalism". In: Joan Connelly Ullman, p. 328 .

39 "The abuses against clergyman (for example the assassination of the bishop) are justified indirectly by the authors using the pretext that they took control of money and riches. [. . .] The iconography is a reminiscence of the old Soviet films about the revolution: The hero is no longer the officer and gentleman of Franco's films, but the mass [the people] and, within it, the individuals forming that mass". In: Xavier Ripoll, 'Los milicianos en el cine', Film-Historia, 3 (I996), 287-294 (p. 292).

$4^{\circ}$ Eric Hobsbawm, Primitive Rebels. Studies in archaic forms of social movement in the I9th and 2oth centuries (London: W. W. Norton \& Company, I965), p. 82. 
Cuando las películas hacen historia portrays churchmen as part of a traitor "reactionary beast". Such treason takes two forms. The first is that churchmen turn out to be not only politically reactionary, but counterrevolutionary, at least in the context of the first half of the $19^{\text {th }}$ century in Andalusia:

[. . .] the Church became not simply a conservative-revolutionary force, as among the small proprietors of Navarre and Aragon [. . .], but a conservative force tout court, in that it joined hands with the wealthy classes. [...] As the social bandits became bandoleros protected by local rich caciques and the Church of the rich, the peasants' dream of a just and a free world had to find a new expression..$^{4}$

The other treason is that, religiously or morally, priests are seen as betraying grassroots Christians, or the cause of supporting the poor, ${ }^{42}$ remaining instead at the service of savage capitalism. In the Spanish imagination, this reactionary betrayal is embodied in the feared triad of the Civil Guard-Cacique-Parish Priest, other times represented as the Bourgeois Capitalist-Soldier-Priest, and even as the Capital/State-Religion-Army. ${ }^{43}$ The triad is synonymous with repression, authority and obedience.

Along similar lines is the anarchist-communist-themed Land and Freedom, a film that tells the story of David Carr (a member of the Communist Party of Great Britain) who fights for the Republicans in the Spanish Civil War in the context of the International Brigades. In the very beginning coincidentally he joins the militias of the POUM (Partido Obrero de Unificación Marxista or Workers' Party of Marxist Unification). After that he ends up joining the Spanish Communist Party (he perceives a greater military efficiency and discipline there) but he is soon disappointed by the internal fights among different left-wing groups,

${ }^{4 I}$ Hobsbawm, p. 8I. A bandolero was an outlaw or bandit, who specially operated in the mountainous Southern areas of Spain. A cacique was a local political boss in Spain, who gained and maintained power thanks to illegal activities such as suborning Church and police, buying votes and terrorising people.

${ }^{42}$ Hobsbawm, p. 83.

43 Lily Litvak, El cuento anarquista, (I880-I9II): antología (Madrid: Fundación Anselmo Lorenzo, 2003), p. 3 I. 
and especially by the repressive ideological purges against POUM members and anarchists because they are the group that most clearly despises blind obedience to hierarchical diktats. At the beginning of the film, a Spanish anarchist militant spokesperson tries to convince the British audience to join the Spanish revolutionary movement stating that: "The big landowners, industrialists, churchmen and army officers feared the growing power of the working class" $(3: 46)$. For Spanish anarchists this reactionary behaviour is even more reprehensible in the case of the clergy because, on the pretext of celebrating the act of worship, they secretly conspired against freedom and terrorised the population by associating the revolution with the realm of the devil. The battle is pitched as one for freedom and against obedience to the forces of the status quo. ${ }^{44}$

This debate over obedience and anarchist freedom is also represented in Libertarias. Pilar - the anarchist woman - discovers María (a former nun) praying and trying to obey and respect all the commandments of the Church while passively witnessing the suffering of Spanish people at war because of these commandments, and Pilar says: "All right, it is time for you to forget this God who is in heaven and for you to take charge of people who are on earth" ( $1: 34)$. Similarly, in the same film, María introduces herself with the traditional Spanish expression: "To serve God and you" (16:00); to which Pilar angrily replies: "Bloody hell! You must not serve God or anyone! From now on you are free!” (I6:03), something that illustrates well the anarchist dislike of any notion of religious obedience.

The most important question arising here is: What is the clergy willing to do on behalf of Christian obedience? The answer is

44 "The machine gun and rifle behind the altars, after saturated images of liturgy and incense, and later impregnated of powder and profanity. [...] There, where under the guise of Catholic worship they conspired against freedom, and they wilted blooming consciences, and the children's minds. They protected and organized usury and all those places covered with holiness fell under the pressure of the furious mass full of courage and they lit with flames the red dawn that was dying the Spanish horizon". Cited in: Santiago Juan-Navarro, 'Un Pequeño Hollywood Proletario: El Cine Anarcosindicalista durante la Revolución Española', Bulletin of Spanish Studies, 4 (20II), 523-540 (p. 528). 
provided by Don Salvador, the young priest of Los girasoles ciegos, who appears as a part of the crusade, as a former WarriorPriest with a uniform and a pistol. ${ }^{45} \mathrm{He}$ confesses to his religious superior that he did not want to fight in the war but says: "I have killed them; I have finished them off on the ground while they looked me in the eye [...]" (5:45). In other words, clergymen have felt forced to perpetrate acts they knew were wrong or at least contrary to biblical instruction.

\subsubsection{Vow of chastity}

In these films, anarchists take an almost sadistic delight in representing the failure of the clergy to keep to the vow of chastity. ${ }^{46}$ As we can see in Libertarias, María, after the outbreak of the Revolution, tries to find a place to hide. Suddenly she discovers in a block of flats an inscription on a door with the portrait of Jesus Christ that says "I will reign". The origin of that inscription comes from the Bible: "He must reign until he shall have put all enemies under his feet" (Corinthians I 5:25). However, the door leads not to a devout place but to a brothel. There, the prostitutes help María and, against her will, undress her while making jokes regarding her odd smell. They ask if nuns do not wash their intimate parts in the convents $(7: 20)$. In the next scene, they force her to hide under a blanket as a regular customer arrives. To María's surprise (and terror), the customer is the city's chubby and lustful bishop (7:30-8:35). In preparation for the sexual intercourse, he

45 According to Miłkowski, the direct military collaboration of churchmen in Franco's trenches was not widespread but was a very limited activity: "Some rare, but most expressive accounts, indicate the direct participation of many Catholic priests in the war - greater than the Catholic hierarchy would like to admit. 'Heraldo de Aragón' informed its readers of chaplains participating in military operations. A practical follower of Huidobro described how, when he was distributing the Holy Communion among convicts prior to their execution, one of them tried to use the opportunity to escape. The priest proudly described catching him himself" (p. 22I).

${ }_{46}$ Pérez Ledesma devotes a very well-researched part of his article to the study of the priestly sexuality entitled: 'Sexuality of the Clergy and Sexuality of the Anticlericals’ (pp. 233-235). 
sarcastically even mentions to María that "God is in control, it will be ok!" (8:40-8:50). When the spectators perceive that they might witness the rape of the nun, and therefore the breaking of her vow of chastity, an armed female anarchist militant enters the room and threatens to kill him if he touches María (I 2:46-I 3:43). The scene contains a clear message for the audience: female-liberation should be in the hands of active women liberating other women from all forms of patriarchy. Notwithstanding, this is not the last time that both María's virginity and her innocence are under threat.

Her new life outside the monastery is packed with challenges and dangers - not always originating from clergymen. For instance, when María and her sisters stroll through the streets, they fear the lascivious and aggressive presence of a group of anarchist militants dressed up in the clothes of religious people. Nonetheless, one of the militants blurts out: "Little nuncomrades, don't be afraid. The revolution respects women, even those of the clergy!" $(5: 40-5: 55)$. However, such a statement is historically inaccurate because in fact 283 religious women were victims of the conflict. ${ }^{47}$ Moreover, as Adriana Cases explains, symbolically " $\mathrm{t}$ ]o rape a sanctimonious woman is equivalent to desecrating places of worship; to rape and kill a wealthy woman is equivalent to sweeping away the old order, and this is part of the revolution that seeks to destroy the system that has been oppressing the people".$^{4}$ In this case, María survived unscathed from all male attacks; she even gets horrified as she witnesses the execution of the same Catholic bishop she encountered earlier in the brothel. She represents the "image of virginal victimization" ${ }^{9}$ given that she does not succumb even to the promise of happiness embodied by her male counterpart; that is, by the anarchist ex-priest who tries to seduce her using both the gospel

${ }^{47}$ Jan Bank \& Lieve Gevers, Churches and Religion in the Second World War (London: Bloomsbury Academic, 2016), p. 90 and Adriana Cases, 'La violencia sexual en la retaguardia republicana durante la Guerra Civil española', Historia Actual Online, 34 (2014), 69-80 (p. 77).

${ }^{4}$ Adriana Cases, p. 77.

49 Maria Van Liew, 'Witness to War: Virginal Vicissitudes in VicenteAranda's Libertarias (1996)', Quarterly Review of Film and Video, 25 (2008), $230-240$ (p. 23I). 
and anarchist principles: "His efforts to court and marry her serve to emphasize the bonds, stronger than her sexual desire for him, with her comrades. She consistently chooses Pilar over him for protection and affection." 5o In these films religious women maintain their chastity and their gendered representations aim to move the spectators toward empathy and respect. By contrast, the representations of lascivious religious men differ radically from those of the religious women.

In a similar vein, in Los girasoles ciegos the young priest Don Salvador spends his nights contemplating pictures of women from the Bible trying to obtain sexual relief using a homemade vagina made from cloths and a pillow. Later his sexual obsessions find a target in Elena López Reinares (Lorenzo's mother). Even though she does not try to seduce him, he develops an unhealthy obsession with her. He sees the young widow as a constant temptation, as the lust of the flesh and the lust of the eyes. He confesses this to his superior and even mentions his involvement with prostitutes during the Spanish Civil War. His superior recommends that he should confess and take care of his instincts. Following this recommendation Don Salvador tries everything he can to consummate his desperate sexual attraction for Elena. One day he even turns up at her house wearing his military uniform thinking that Elena might accept him as a man and as a fighter, rather than as a representative of the clergy. Nevertheless, as soon as the priest discovers that his lust is not reciprocated, he attacks and destroys the whole family. Ricardo Mazo Torralba, Elena's husband, who for more than five years had remained hidden - as a topo $0^{5 \mathrm{I}}-$ in the attic, cannot stand the attempted rape of his wife and leaves his hiding place to fight Don Salvador. Finally, knowing that he will probably be shot as a result, Ricardo jumps out of a window. For Catholic critics, such moments in the film made it "in these

50 Maria Van Liew, p. 237.

${ }^{51}$ Topo [literarily a mole] is the unofficial term used to describe those who lived hidden after the Civil War to avoid the Francoist repression. Two good researches on this issue are: Ronald Fraser, In hiding: the life of Manuel Cortes (New York: Pantheon Books, I972), and Jesús Torbado and Manuel Leguineche, eds, Los topos: el testimonio estremecedor de quienes pasaron su vida escondidos (Barcelona: Argos, I980). 
years of examining the behaviour of priests and their training, an intense look at the sexual conflicts of those who follow a priestly vocation"..$^{2}$

In contrast, Jesús Arnal (Buenaventura Durruti's ${ }^{53}$ secretary and a former priest) is represented differently. ${ }^{54}$ While the bishop in Libertarias who visits prostitutes is soon shot, Jesús Arnal represents a member of the anarchist militia, but a special one. $\mathrm{He}$ also is (or was) a churchman; however, he believes in the anarchist revolution (including the sexual one) and he tries to have a romantic relationship with María (the nun), although she rejects him. ${ }^{55}$ The spectator is left with a different representation of the moral and political standing of the two priests: the fascist priest is bad and impure, while the anarchist priest is good and relatively pure.

\subsubsection{The seal of the confessional}

In addition to their portrayal of the failure to keep to the religious vows of poverty and charity, and to their willingness to blindly follow the vow of obedience, these films further highlight the violation of the vow of silence that is implicit in confession, also called the seal of the confessional. To take an example from Land and Freedom, in one scene a parish priest indiscriminately shoots from the bell tower of the church to resist the collectivization of the building and the land. Later he denies being the gunman but is exposed before the crowd as a liar as he has a large bruise on his shoulder, a mark caused by the continued use of a rifle. In

${ }_{52}$ Blind Sunflowers (Los Girasoles Ciegos), (Roma: Signis world Catholic association communication, March-June 2009) <http://www.signis.net/ article.php3 id_article $=3$ I $63>$ [accessed Io January 20I3] .

${ }_{53}$ In the Spanish anarchist movement, Buenaventura Durruti (I896-I936) was described as a revolutionary hero. He died shot under strange circumstances while defending Madrid from the fascists.

${ }_{54}$ Luisa Marco Sola, 'Si Jesucristo estuviera en el mundo formaría también en estas milicias populares. La memoria de la Iglesia disidente', Historia y Memoria, 3-4 (2007), I-I4 (pp. 9-10). <http://www.todoslosnombres. org $/ \mathrm{php} /$ generica.php? enlace $=$ muestradocumento\&iddocumento $=\mathrm{I} 00>$ [accessed 20 July 20I2].

${ }_{55}$ Lee, p. 102. 
the face of this irrefutable evidence, the people of the village call for immediate justice and instant execution. In this sequence, the spectator is encouraged to empathize with the act of justice that the pueblo demands. Nonetheless, this empathy is the fruit of the dramatization of history referred to earlier, "the passion trap", "where the passions of the war filter into [the] construction of the story and infect the story with either heart wrenching shouting or overly emotive writing". ${ }^{56}$ The tension of the sequence rises when a woman further accuses the priest of being responsible for the execution of five young anarchist CNT members, one of them having previously told the priest during confession where the men had been hiding from the Civil Guards. It then becomes clear that the priest had undeniably violated the seal of the confessional and gone immediately to the Civil Guards to denounce the men. Here again, a priest is portrayed as betraying a moral code which is supposed to be defining to his profession. As a consequence of his incrimination, the five young CNT members died in an ambush. Faced with the evidence of such betrayal, the militia members shoot the priest and burn the relics from the church. ${ }^{57}$

\section{New conceptions of religion in Spanish anarchist films}

Even though the old anticlerical sentiments are clearly represented in these contemporary anarchist films, the emergence of new conceptualizations can also be observed, which I have grouped under two themes outlined below.

Firstly, in those films there is a timid and conciliatory tone linked to a set of principles derived from the ethics of the early Christians (prior to the emergence of the centralized Roman Catholic Church). Some parts of the films seem to seek a certain

${ }^{6}$ Paul Doyle, The Anarchist's Wife - A Review, (Seattle: By the Firelight, 28 May 2009). <http://bythefirelight.com/2009/05/28/the-anarchistswife-a-review/>. [accessed 7 January 20I3]

57 "This is in contrast to the scene in Loach's Land and Freedom where anticlericalism is incidental yet explained by the priest shooting at the militia from his bell tower. When the priest is captured with a rifle and the marks on his shoulder to prove his firing, he is shot. Aranda's anticlericalism is much more important but also much more muddied and unexplained and as a consequence, irrational". In: Lee, p. IO3. 
peace with Catholicism, but not with the Church as an institution. Secondly, these films also display a certain indifference towards religion, which could be interpreted as a form of tolerance for individual beliefs. In other words, as long as religion is kept within the private domain and does not interfere with the public sphere, anarchism will respect it. ${ }^{8}$ The religious issue in contemporary films is either simply ignored, or diluted by problems that were more relevant to the working class. There is arguably a third iconography in the projected images of these films, which is that the religious class appears as ideologically sick but likely to be "cured" if invited to partake in "the banquet of life", 59 that is, by the adoption of anarchist vital principles. However, as this iconography is not as prevalent as the other two in the films analysed here, and as I discuss it elsewhere, it will not be discussed here. ${ }^{60}$

\subsection{The other Church (Grassroots Christians)}

Despite my opening description of the Francoist Christian crusade against atheism, Judaism and Freemasonry, and the fact that some historians refer to the Church at that time as "puritan and pro-government", ${ }^{61}$ there was never a homogeneous church in Spain either during the Civil War or during the Franco Regime. At the heart of these films what we also see represented is the so-called "other Church", composed of grassroots Christians. In some ways, anarchists seem to be tolerant towards this early Christianity and also towards an ideology close to Liberation

$5^{8}$ "A common position in modern philosophy is that the religious beliefs a person holds are of a personal, existential nature and should play no role in typically secular enterprises like science and politics, where the arguments offered should be accessible to anyone". In: Hendricus Johannes Prosman, 'Secularity: Premodern, Modern, Postmodern', Ars Disputandi supplement series, 4, 20I I, 3 I-70 (p. 65).

59 Anselmo Lorenzo, El banquete de la vida. Concordancia entre la naturaleza, el hombre y la sociedad (Barcelona: Sintra, 2006).

${ }^{60}$ Pedro García-Guirao, 'Pobres pero honradas: Lujuria burguesa y honorabilidad proletaria en las novelas breves de Federica Montseny', International Journal of Iberian Studies, 24 (201 I), I 55-177 (pp. I67-168).

${ }^{6 r}$ José Rubio Hernández, El movimiento obrero en el cine (Murcia: Universidad de Murcia, 2009), p. 27. 
Theology that symbolically raises Jesus Christ's flag. ${ }^{62}$ The revolution becomes a bonfire upon which the old evils of the working class, including religion as stereotypically perceived, are burnt in order to make way for a new world, ${ }^{63}$ but in this new world religion is not necessarily something wrong, or something that cannot be reconciled with anarchism. ${ }^{64}$ In fact, these anarchists try to rescue the Christian principles that they are sympathetic to, and attempt to integrate them into anarchist ideology. For them, God is not the same as Jesus Christ, just as the Church is not the same as religion or mysticism. These ideas seem to echo Leo Tolstoy's objections against the ecclesiastic faith, which he considered diametrically opposed to Christ's teaching. ${ }^{65}$

Thus, in La mujer del anarquista, during the siege of Madrid by the Condor Legion, the terrified reds - including the anarchists pray in the basement of a building for the bombing to end. In the same film, the main anarchist character (Justo) is religiously married to Manuela, who is originally from a religious and wealthy right-wing family. Nevertheless, when they go into exile in France, Manuela wants to go to church to light a candle to keep her promise to God for safely reuniting the whole family. As for Justo, even though he says that he will never enter a Church again in his life, that does not necessarily make him an atheist. Similarly, in Libertarias, Floren, a club-footed anarchist who owns a library

${ }_{62}$ See Linda H. Damico, The Anarchist Dimension of Liberation Theology (New York: P. Lang, I987).

${ }_{3}$ In this sense, Pérez Ledesma states that "the destructive work of all of them [anticlerical movements] was a response to the need to put an end to the symbolic system of traditional societies, to which the Church lent its ideological and bureaucratic apparatus, in order to give way to a modern, middle-class, secularized and individualist society" (pp. 240-24I).

${ }^{64}$ Some authors argue something different: "Therefore, religion is not what interests anarchists regarding Christianity, but the desire of Jesus to defend his truth, even paying with his life, which is a shared truth as a defence of justice and of the value of those who are unprotected and weak; those, by binding to a belief, can be strong inside”. In: Jorge Urrutia Gómez, 'El retorno de Cristo, tipo y mito', Anales de literatura española, I 5 (2002), 237-255 (p. 238).

${ }_{5}$ See Leo Tolstoy, The Kingdom of God Is Within You Or, Christianity Not as a Mystical Teaching but as a New Concept of Life (New York: Editions Artisan Devereaux, I927). 
and who can communicate with the spirits of some presumably dead Spanish anarchists, discusses the existence of God with María, the former nun. Floren believes in God but nevertheless blurts out that: "God is a fascist" (3 I:40). She also describes Jesus Christ as the first anarchist in history and places her religious sentiments in seeming contradiction with those of the papal Church: "I believe in Jesus Christ but not in priests" (33:05). She shocks María with this assertion (even though it was a quite widespread belief among anarchists) ${ }^{66}$ as well as with her confessed belief that Jesus Christ is a woman (33:22).

That religious men and women are respected in these films only if they rebel against the established Church can also be seen in Libertarias, where María, after meeting Floren and being exposed to anarchist readings, becomes a new person. She still believes in religion, but in a polarized and revolutionary form that has no place for the Church hierarchy. She favours the Christian spirit and what might be called early Christianity, opposed to the papal church. All these ideas lead us to the historical figure of Jesus Christ, not as the passive man of the cross but as the fighter, the radical propagandist, one who is principally a militant, a persecuted pariah, an accused man and, above all, someone without rituals, churches or intermediaries between humankind and its own liberation. ${ }^{67}$

In any case, the turning point in the representation of this new Spanish Church begins to develop in the aftermath of the Second Vatican Council (I962-5):

The Church in Spain was one of the most forceful democratizers in the Catholic wave [which is the label Diamond et al give to the third wave of democratisation, to note the role of Catholicism in it]. It is also one of the churches upon which Vatican II exercised its strongest influence. Among the factors that caused the demise of Spanish authoritarianism, the Church's opposition was

66 See Aníbal Vaz de Mello, Cristo, el Anarquista. Estudio sobre la personalidad y filosofía de Jesús de Nazaret (Editorial Claridad: Buenos Aires, I936), and Urrutia, pp. 237-247.

${ }^{67}$ See Matías Usero Torrente, 'La Iglesia Católica y su Política', Orto. Revista de Documentación Social, Io (I932), 20-23 (p. 20) and Urrutia, pp. 237-247. 
arguably the most formidable. Paradoxically, though, the Church did not apply this resistance through energetic popular participation, but rather through its power of withdrawal. It significantly aided democratization by deciding no longer to support the regime of Generalissimo Francisco Franco. ${ }^{68}$

It is worth remembering that part of the old Church had collaborated directly with Francoism. The Church finally acknowledged, some thirty years later, the mistake that it had committed by becoming directly involved with the political purges of the Franco Regime. The process of separation of Church from State in Spain started in the late I960s. ${ }^{69}$ After the Second Vatican Council, the Church became a real driving force for social justice in Spanish communist, socialist and trade unionist clandestine assemblies. ${ }^{70}$ This social phenomenon can be seen, for example, in the anarchist film Salvador. The film describes the life of the Catalan anarchist Salvador Puig Antich, the last person executed by garrotte (a medieval weapon used for strangulation) in March 1974 under the dictatorship of a dying Franco, who would die on 20 November I975. In the film, Oriol Arau, the young lawyer who is trying to save Salvador Puig Antich's life, promotes a social campaign where groups of Christians play a prominent role, so much so that a plea of mercy is sent by the Vatican to save Salvador from execution. Unfortunately, Franco decides to execute the death sentence passed on this young anarchist. ${ }^{{ }^{1}}$ Despite this injustice,

${ }^{68}$ Larry Diamond, Marc F. Plattner, and Philip J. Costopoulos, eds, World religions and democracy (Baltimore: JHU Press, 2005), p. I07.

69 "In the sixties and seventies social secularization took a centre stage. [Secularization was] understood as a reduction to the private sphere of religion and as a desecration of a worldview. But rather than a decline of religious feelings, there was a crisis in the institutional and rituals of Catholicism”. In: Mónica Moreno Seco, 'Creencias religiosas y política en la dictadura franquista' Pasado y memoria: Revista de historia contemporánea, I (2002), I-53 (pp. 22-23).

70 For an analysis on the Vatican hostility to Franco Regime see Paul Preston, The triumph of democracy in Spain (London: Routledge, 2003). ${ }_{71}$ "Franco decided to go ahead with the executions despite European protests, the clemency request by Pope Pablo VI, and Franco's own brother Nicolás' objections”. In: Tatjana Pavlovic, Despotic bodies and transgressive bodies: Spanish culture from Francisco Franco to Jesús Franco (New York: SUNY Press, 2012), p. 79. 
a new self-understanding of Catholicism, which had taken root with the Second Vatican Council, was emerging, and was based on three principles mentioned earlier: a) Internalized and living piety, that is, a religion which is more optimistic and in which the act of adoring God is substituted by acting as Christ; b) Criticism of the economic system and opposition to the dictatorship; and c) Plurality in understanding religion..$^{72}$ As the implications of the Second Vatican Council took hold in Spain, the church's view of the regime changed, which in time made it easier for later films to evoke the possibility of "the other Church".

A matter of vital importance in the anarchist interpretation of "the other Church" is the figure of the militant priest, and that figure is the one which appears in Libertarias: Jesús Arnal, Durruti's secretary. In fact, Durruti saved him from execution by anarchist milicianos. The leader of the anarchists told them: "We shall not do anything to the priest because he is one of us". At the beginning of the film, he has a theological discussion with María (the nun), who asks for clarifications on his views about religion, to which he replies: "Jesus Christ (your Lord) told us that the poor are holy" (OI:03:48). And later: "On the day of the Resurrection Jesus Christ will emerge with a raised fist" (OI:29:IO). These words clearly illustrate a take on Christianity very different to the old anarchist anticlerical sentiments.

\subsection{The notion of secularization}

Finally, it is worth discussing the way in which religious tropes are "secularised" in these anarchist films. In Libertarias, an American journalist - presumably Ernest Hemingway - somewhat surprisingly claims that: "Some argue that anarchism is just a religious statement" (OI:32:I2). What he seems to mean is that anarchists pay such attention to the anarchist corpus, they would put such effort in the dissemination of the anarchist principles, they believe so blindly in the idea of revolutionary fury (as the salvation for the misery of the people), and they are so committed to a future social justice (as a kind of avenging apocalypse) that they are

${ }^{72}$ Moreno Seco, pp. 25-27. 
comparable to those faithful to their Catholic religion (studying the Holy Scriptures closely, having faith in the end of the times, spreading the word of Christ and having an intense Christian commitment to social justice). Anarchism, in that sense, is merely a transposition of religion or a substituted religion: "Anarchism is not in Libertarias an ideology that attracted adherents but rather - and certainly for María - a substitution for Catholic religious faith". ${ }^{73}$ This idea seems ridiculous for Pilar (she replies to the American journalist: "No God, No master!"). After all, perhaps she sees the characterisation of anarchism as religion as worrying.

In any case, Antonio Rabinad and Vicente Aranda (the film's screenwriters) seemed to be hinting at this argument about traditional Spanish anarchism's millenarian qualities ${ }^{74}$ when they wrote the aforementioned scene. According to Grace Duncan, this stereotyped identification between anarchism and religious millennialism has been influenced by the work of numerous historians who have tended to use in their books "images and metaphors identifying the [anarchist] movement with the essence of Spain, with the biblical past, with profound emotion, and idealized childhood". ${ }^{75}$

In the literature on secularization in political theology, ${ }^{76}$ depending on the interpretation, "secularization" works at least in three ways: ${ }^{77}$ I) as a transposition of religious concepts to non-religious ones; 2) as an ideological transformation where religious concepts are reinterpreted; and 3) as emancipation from the Biblical heritage (as a progressive liquidation of religious rituals, symbols,

73 Lee, p. IO3.

${ }^{74}$ For a study on this debate see: Martha Grace Duncan, 'Spanish Anarchism Refracted: Theme and Image in the Millenarian', Journal of Contemporary History and Revisionist Literature, 3 (I988), 323-346. And, Hobsbawm, Primitive Rebels.

75 The historians in question include Constancio Bernaldo de Quiros, Franz Borkenau, Gerald Brenan, J. Diaz del Moral, E. J. Hobsbawm, Edward Malefakis and Stanley G. Payne. Martha Grace Duncan, p. 324.

${ }^{76}$ See Jean-Claude Monod, La querelle de la sécularisation: Théologie politique et philosophies de l'histoire de Hegel á Blumenberg (Paris: Vrin, 2002).

77 Prosman, p. 68. 
and any public religious spheres of power, implementing a lay society). ${ }^{78}$ These films I) interestingly borrow religious concepts; 2) use symbolism and imagery and apply those to the anarchist cause; and 3) celebrate emancipation from religious dogma and rituals.

One clear example of such secularization of religious tropes can be found at the end of Libertarias. The film ends with María reciting a secular and revolutionary prayer for Pilar, who is bleeding to death after Francoist Moorish troops have slit her throat:

One day that is already in our Lord's time, this planet called Earth that we step on, will cease to be called Earth and will be called Freedom. That day the exploiters of the people will be cast into outer darkness where there will be weeping and gnashing teeth. And the angels of heaven, at the top, will sing songs of joy while beholding the Freedom star, bluer and brighter than ever. Because upon that star will reign Peace and Justice, so a paradise will be there forever, and Death will not exist anymore (or:56:00).

The image suggests messianic hope in the coming, not of the Lord, but of a revolutionary apocalypse that will sweep away injustice and pain from the Earth. While the film finishes with an ostensibly dramatic ending, María's prayer surrounded by debris encompasses a promise of happy-ending for the disinherited of the "banquet of life". The focus on María in the final sequence of the film is thus intended to further emphasize her representation as "the anarchist Messiah". ${ }^{79}$

Another film in which religious tropes appear secularised and reproduced by anarchists is El corazón de la tierra. The film is based on the I 888 strikes by syndicalist miners in Rio Tinto (Huelva, Spain), led by the Cuban anarchist Maximiliano Tornet, against the Rio Tinto Company, a British multinational metals and mining corporation. The protests were ferociously repressed as a

${ }^{78}$ See Mark Chaves, 'Secularization as Declining Religious Authority', Social Forces, 72 (I994), 749-774.

79 Jo Labanyi 'The Politics of the Everyday and the Eternity of Ruins: Two Women Photographers in Republican Spain (Margaret Michaelis I93337, Kati Horna 1937-38)', in Cultural Encounters: European Travel Writing in the I930s, eds. by Charles Burdett and Duncan Derek (New York: Berghahn Books, 2002) 85-I06 (p. 9I). 
Spanish mercenary army bribed by the British massacred many of the miners. In the film, Tornet is represented as a martyred, revolutionary Jesus Christ. When Tornet comes to Rio Tinto (Huelva) in 1883 , the British owners of the opencast mines see him as a dangerous "anarchist apostle". ${ }^{\circ} \mathrm{He}$ uses the Bible in his speeches, but revises Biblical messages to replace them with revolutionary ones. So, where the Bible says "Blessed are those who hunger and thirst for righteousness, for they will be filled" (Matthew 5:6) and "Blessed are those who are persecuted because of righteousness, for theirs is the kingdom of heaven" (Matthew 5:IO), Tornet comments: "No! Blessed are those who are rebels, those who fight for the land, those who conquered it, and those who take what belongs to them. [...] No! What about the right here and the right now? Don't wait so long. Blessed are those who fight for freedom; blessed are those who demand their rights and blessed are those in whose hearts conscience and dignity lives. Yes! Let us be blessed!" (8:37). His power of persuasion, leadership and charisma inspired many and led to one of the bloodiest strikes in nineteenth-century Spain. Tornet's death provides another example of this kind of secularization: not only do his words remind us of Jesus Christ (Matthew 5:6 and Matthew 5:IO), but so does his death at the hands of the powerful mine owners. After beating him, they slit his throat and throw his body into the sea where, as it is slowly sinking, the movements of his body are clearly reminiscent of the Crucifixion. A new anarchist martyr was born. We also see this kind of secularization permeating non-religious humanist and civil funeral ceremonies held in these anarchist films. For example, in Land and Freedom, during Coogan's (an Irish Republican member of the International Brigades) funeral his compañeros sing "The Internationale" instead of praying, and the same happens with Blanca's funeral. The religious content of the ritual is emptied and replaced with new anarchist imagery. In any case, like Pilar in Libertarias, not everyone accepts such a millenarian reading of Spanish anarchism. For example: “[. . . Kaplan feels that to call anarchism a quasi-religious or secular millenarian movement is to denigrate it: 'In a secular age, the taint of religion

${ }^{8 \circ}$ Hobsbawm, p. 80. 
is the taint of irrationality'". ${ }^{8 \mathrm{I}} \mathrm{I}$ have shown, however, that secularised religious tropes are visible in some of the anarchist practices as portrayed in these films.

\section{Conclusion}

The historical tensions between anarchists and churchmen during the Spanish Civil War were real. As put in Libertarias (I 2:23), "Priests and nuns [had to] flee to hide like rats in view of the rising sun of proletarian justice". Needless to say, this "proletarian justice" was just a euphemism for the use of violence against the clergy as a social group: "On the whole, about seven thousand members of the clergy were killed, including I 3 bishops, 4I84 priests, 2365 monks, and 283 nuns during the Civil War in Spain". ${ }^{82}$

In the end and despite the above discussion, it seems that neither the passage of time nor the democratization of Spain have yet brought an attempt to reconcile anarchist principles with those of the post-Second Vatican Council Catholic Church. The two positions remain far apart. One reason for this irreconcilable conflict is precisely the continued prevalence of those anticlerical sentiments inserted deeply in the anarchist worldview which are so well represented in these films. Perhaps another reason can also be found in the problematic depictions of history which can be reinforced when films such as those discussed here are accepted as historically accurate. My contention is that the authors and film directors did not necessarily aim to tell the historical truth of the events portrayed, yet their rendering of those events are interesting indicators of the way those are remembered and interpreted by the society the films were made in. Moreover, the historians, academics and critical analysts among us must guard against the risk of taking as accurate the potential and intentional lies, reinventions of history, and silences contained in these anarchist films. Besides, "An uncovered lie might function as a red flag, alerting a historian to an area where she should dig

${ }^{81}$ Martha Grace Duncan, p. 334.

${ }^{82}$ Miłkowski, p. 2 Iо. 
little deeper". ${ }^{83}$ The films discussed here should therefore not be read in isolation, but along with secondary scholarship about the time-period in question - both of the film and the history.

As I have shown in this essay, from Land and Freedom (I995) to El cine libertario: Cuando las peliculas hacen historia (20I I), contemporary Spanish anarchist-themed films have been engaged in representing the history of Spain using old antireligious sentiments and new representations of religion. However, in all of them the conception of the Church as a counterrevolutionary force and as a corrupt and greedy institution tends to dominate portrayals of religion. To a large extent, these films indulge in a long tradition of anticlericalism in Spain: "Anticlericalism was a decisive trend in Spanish political, social and cultural life from the beginning of the nineteenth century until the Spanish Civil War". ${ }^{84}$ The films therefore embrace a social tension that has operated in Spain for at least two centuries, between the forces of secular ideologies (sometimes with outright hostility to religion) and those that treat traditional religious values and institutions as necessarily a matter of identity (Spanishness, in this case).

At the same time, the films also represent the prelude to a new secularized world which, in the case of Spain, arguably started in I93 I with the Second Spanish Republic, stopped violently in I939, and restarted after Franco's death. In this sense: “[. . .] historical films too should be seen not as a return to the past but as a means of negotiating the relationship of the past to modernity. That is, the spectator travels to the past temporarily so as to rework his or her position in the present". ${ }^{85}$ Therefore, contemporary viewers of these films are made to contemplate the unstoppable process of secularization that Spain has been experiencing since the adoption of the 1978 Constitution. In the end, this historical process is a key factor for understanding the relationship between contemporary Spanish anarchist films and religion. Moreover, the major Spanish

${ }_{3}$ Jennifer Jensen Wallach, 'Building a bridge of words: The literary autobiography as historical source material', Biography, 3 (2006), p. 450.

${ }^{8} 4$ Pérez Ledesma, p. 227.

${ }^{85}$ Jo Labanyi, 'Negotiating modernity through the past: costume films of the early Franco period', Journal of Iberian and Latin American Studies, I3 (2007), 24I-258 (p. 24I). 
anarcho-syndicalist union, the CNT, regards religious issues in a more conciliatory way than any stereotypical depiction might assume. According to the CNT' statutes:

Any worker can join the union, regardless of their political or religious views. They only have to accept our associative agreement and respect the decisions made in assembly. CNT is an independent organization [. . .]. To preserve this independence, members of political parties or religious organizations cannot use the union as a forum in which to promote those organizations and cannot hold offices. $^{86}$

This official position coincides with most of the new representations of religion analysed in this essay. These new representations suggest that religion must be kept within the private domain, that the official Church and the individual practice of religion or mysticism must be distinguished, and that early Christianity, and the idea of practicing what Jesus Christ preached are worth recovering and giving space to in an anarchist society.

\section{References}

Archibald, David, 'The war that won't die', The Guardian, 28 July 2000. <http://www.guardian.co.uk/film/2000/jul/28/culture.features I > [accessed 9 January 20I3]

- The War That Won't Die: The Spanish Civil war in Cinema (Manchester: Manchester University Press, 2013).

Bakunin, Mikhail, God and the State (New York: Cosimo Classics, 2008).

Bank, Jan \& Gevers, Lieve, Churches and Religion in the Second World War (London: Bloomsbury Academic, 2016).

Boyd, Carolyn P., 'The Anarchists and Education in Spain, I 868-I909', The Journal of Modern History, 48.4 (I976), I25-I70.

\footnotetext{
86 'Who can belong to CNT?' <http://www.cnt.es/en/who-can-belong-cnt>
} [accessed I 4 February 20I 5]. 
Blind Sunflowers (Los Girasoles Ciegos), (Roma: Signis world catholic association communication, March-June 2009) <http://www.signis. net/article.php3 ?id_article $=3$ I 63 $>$ [accessed Io January 20I3]

Campbell, Duncan, 'A revolution in cinema?', The Guardian, 24 November 2006. <http://www.theguardian.com/film/2006/nov/24/I> [accessed I 5 July 20I3]

Caplan, Nina, 'Butterfly's Tongue', Daily Mail, I4 November 2000. <http://www.dailymail.co.uk/tvshowbiz/article-635 I/ButterflysTongue.html> [accessed Io January 20I3]

Caro Baroja, Julio, Introducción a una historia contemporánea del anticlericalismo español (Madrid: ISTMO, I980).

Cases, Adriana 'La violencia sexual en la retaguardia republicana durante la Guerra Civil española', Historia Actual Online, 34 (2014), 69-80.

Chaves, Mark, 'Secularization as Declining Religious Authority', Social Forces, 72 (1994), 749-774.

Crusells Valeta, Magí, 'Cinema as a political propaganda during the Spanish Civil War: España I936’, Ebre, 38, (2004), I-I2.

Diamond, L., Plattner, M. F. and Costopoulos P. J., eds, World religions and democracy (Baltimore: JHU Press, 2005).

Doyle, Paul, The Anarchist's Wife - A Review, (Seattle: By the Firelight, 28 May 2009). <http://bythefirelight.com/2009/05/28/ the-anarchists-wife-a-review/>. [accessed 7 January 20I3]

El cine libertario: Cuando las películas hacen historia, dirs. by José María Almela and Verónica (Vigil. Delta Films / Canal de Historia. 2OII) [on DVD]

El corazón de la tierra, dir. by Antonio Cuadri (Future Films, Manufacturas Audiovisuales, Costa do Castelo Filmes, Sequence Film, Surinvest Capital Andalusia, 2007) [on DVD]

Espigado Tocino, M. Gloria, 'El analfabetismo en España. Un estudio a través del censo de población de I877', Trocadero: Revista de historia moderna y contemporanea (I990), I73-I92.

Fidler, Geoffrey C., 'The Escuela Moderna Movement of Francisco Ferrer: 'Por la Verdad y la Justicia", History of Educations Quarterly 25 (I985), IO3-I32. 
Filmaffinity. < http://www.filmaffinity.com> [accessed 2 January 20I3]

Foucault, Michel, 'Right of Death and Power over Life', in The History of Sexuality. Vol. Volume I. An Introduction (Harmondsworth: Penguin Books, I990), I33-I59.

Fraser, Ronald, In hiding: the life of Manuel Cortes (New York: Pantheon Books, I972).

García, Rocío,'La otra vida de Los girasoles ciegos’ ElPaís, 22 October 2007. http://elpais.com/diario/2007/Io/22/cultura/I I 93004003 _8502 I 5 . html [accessed o2 October 20I3]

García-Guirao, Pedro, 'Francisco Ferrer y las misiones pedagógicas del anarquismo español' (Murcia: Biblioteca Saavedra Fajardo, 2007). http://saavedrafajardo.um.es/WEB/archivos/NOTAS/RESoo78.pdf [accessed I7 September 20I3], I-I4.

— ' 'Pobres pero honradas: Lujuria burguesa y honorabilidad proletaria en las novelas breves de Federica Montseny', International Journal of Iberian Studies, 24 (20I I), I 5 5-I77.

Grace Duncan, Martha, 'Spanish Anarchism Refracted: Theme and Image in the Millenarian', Journal of Contemporary History and Revisionist Literature, 3 (I988), 323-346.

Hobsbawm, Eric, Primitive Rebels. Studies in archaic forms of social movement in the I9th and 2oth centuries (London: W. W. Norton \& Company, I965).

$I M D b .<$ http://www.imdb.com/ > [accessed 2 January 20I3]

Juan-Navarro, Santiago, 'Un Pequeño Hollywood Proletario: El Cine Anarcosindicalista durante la Revolución Española', Bulletin of Spanish Studies, 4 (20I I), 523-540.

La lengua de las mariposas, dir. by José Luis Cuerda (Las Producciones del Escorpión, SOGETEL, Grupo Voz, Canal Plus, TVG, Televisión Española, I999) [on DVD].

La mujer del anarquista, dir. by Peter Sehr and Marie Noëlle (KV Entertainment, Zip Films, P'Artisan Filmproduktion GmbH, Ciné Boissière, Instinctive Film, 2009) [on DVD].

Labanyi, Jo, and Pavlović, Tatjana, eds, A Companion to Spanish Cinema (Oxford: Wiley-Blackwell, 20I2). 
Labanyi, Jo, 'Negotiating modernity through the past: costume films of the early Franco period', Journal of Iberian and Latin American Studies, I3 (2007), 24I-258.

— 'The Politics of the Everyday and the Eternity of Ruins: Two Women Photographers in Republican Spain (Margaret Michaelis I933-37, Kati Horna I937-38)', in Cultural Encounters: European Travel Writing in the I930s, eds. by Charles Burdett and Duncan Derek (New York: Berghahn Books, 2002) 85-ı06.

Land and Freedom, dir. by Ken Loach (BBC, PolyGram Filmed Entertainment, British Screen Productions, Eurimages, Messidor Films S.L., Working Title Films, Degeto Film, Road Movies Dritte Produktionen, BIM, Filmstiftung Nordrhein-Westfalen, European Co-product, I995) [on DVD].

Lee, Andrew H., 'Libertarias', in Arena I: On Anarchist Cinema, ed. by Richard Porton (London: PM Press, Christie Books, 2009), 99-106.

Libertarias, dir. by Vicente Aranda (TVE, Lolafilms, Canal+ España, Sogetel, Sogepaq, Academy Pictures, Era Films, I996) [on DVD].

Litvak, Lily, La mirada roja: estética y arte del anarquismo español (I880-I9I3) (Barcelona: Serbal, I988).

- El cuento anarquista: I880-I9II: antología (Madrid: Fundación Anselmo Lorenzo, 2003).

Lorenzo, Anselmo, El banquete de la vida. Concordancia entre la naturaleza, el hombre y la sociedad (Barcelona: Sintra, 2006).

Los girasoles ciegos, dir. by José Luis Cuerda (SOGECINE S.A., Estudios Organizativos y Proyectos Cinematográficos S.L., 2008) [on DVD].

Marco Sola, Luisa, 'Si Jesucristo estuviera en el mundo formaría también en estas milicias populares. La memoria de la Iglesia disidente', Historia y Memoria, 3-4 (2007), I-I4. <http://www. todoslosnombres.org/php/generica.php?enlace=muestradocumento\&iddocumento $=\mathrm{IOO}>$ [accessed 20 July 20I2]

Miłkowski, Tadeusz, 'The Spanish Church and the Vatican during the Spanish Civil War', The Polish Foreign Affairs Digest, 3 (2004), 207-242. 
Monod, Jean-Claude, La querelle de la sécularisation: Théologie politique et philosophies de l'histoire de Hegel á Blumenberg (Paris: Vrin, 2002).

Moreno Seco, Mónica, 'Creencias religiosas y política en la dictadura franquista' Pasado y memoria: Revista de historia contemporánea, I (2002), I-53.

Nettlau, Max, A Short History of Anarchism (London: Freedom Press, 1996).

Olmo, 'Crítica de la película Los girasoles ciegos', (Precríticas, 3 October 2008). <http://www.precriticas.com/criticas/la-lenguade-los-girasoles/> [accessed Io January 2013]

Pais de Lacerda, António, 'Cinema as an Historical Document: AIDS in 25 years of Cinema', Journal of Medicine and Movies, 2-3 (2006), IO2-II3.

Paradelo Núñez, Martín, 'El mundo a través de un cristal. Alcance crítico de los modos de representación cinematográficos', Estudios. Revista de Pensamiento Libertario, 2 (2012), 76-гог.

Pavlović, Tatjana, Despotic bodies and transgressive bodies: Spanish culture from Francisco Franco to Jesús Franco (New York: SUNY Press, 20I2).

Mundabor, 'Pope Pius XII's Message after the Victory in Spain. I4 April I939'. < http://mundabor.wordpress.com/20I I/O7/2I/popepius-xiis-message-after-the-victory-in-spain/> [accessed 26 July 2OI2]

Pérez Ledesma, Manuel, 'Studies on Anticlericalism in Contemporary Spain', International Review of Social History, 46 (200I), 227-25 5.

Porton, Richard, Cine y Anarquismo. La Utopía Anarquista en Imágenes (Barcelona: Gedisa, 200I).

- On Anarchist Cinema. Anarchist Film and Video (OaklandSussex: PM Press-ChristieBooks, 2009).

Preston, Paul, The triumph of democracy in Spain (London: Routledge, 2003).

Prosman, Hendricus Johannes, 'Secularity: Premodern, Modern, Postmodern', Ars Disputandi supplement series, 4, 20 I I, 3 I-70. 
Rayner, Philip, Wall, Peter and Kruger, Stephen, AS media studies: the essential introduction. (London: Routledge, 2004).

Ripoll, Xavier, 'Los milicianos en el cine', Film-Historia, 3 (I996), 287-294.

Rosenstone, Robert, 'The historical film as real history', Film-historia online, I (1995), 5-23.

Rubio Hernández, José, El movimiento obrero en el cine (Murcia: Universidad de Murcia, 2009).

Rutledge Southworth, Herbert, Conspiracy and the Spanish Civil War. The Brainwashing of Francisco Franco (London: RoutledgeCañada Blanch Studies, 2002).

Sáez González, Jesús Miguel, 'Reseñas de cine', Vivat Academia, I I 2 (2008), I-9.

Salvador (Puig Antich). dir. by Manuel Huerga (MediaPro/Future Films, 2006) [on DVD]

Schwartz, Stephen, 'The paradoxes of film and the recovery of historical memory: Vicente Aranda's works on the Spanish Civil War', Film History: An International Journal, 4 (2008), 50I-507.

Susman, Warren I, 'Film and History: Artefact and Experience', in Hollywood and the American Historical Film, ed. by J.E.Smyth (London: Palgrave-Macmillan, 20I I), I-I I.

Terzioska, Jasmina, Use and Abuse in the Educational Apparatus during Franco's Regime in Spain: (1936-I95I) (Unpublished thesis, University of Cincinnati, 2009).

Tolstoy, Leo, The Kingdom of God Is Within You Or, Christianity Not as a Mystical Teaching but as a New Concept of Life (New York: Editions Artisan Devereaux, I927).

Torbado, Jesús and Leguineche, Manuel, eds, Los topos: el testimonio estremecedor de quienes pasaron su vida escondidos (Barcelona: Argos, I980).

Ullman, Joan Connelly, The tragic week: a study of anticlericalism in Spain, I875-I9I2 (Cambridge: Harvard University Press, I968).

Uroz, José, ed., Historia y cine (Alicante: Universidad de Alicante, I999). 
Urrutia Gómez, Jorge 'El retorno de Cristo, tipo y mito', Anales de literatura española, I 5 (2002), 237-255.

Usero Torrente, Matías, 'La Iglesia Católica y su Política', Orto. Revista de Documentación Social, Io (I932), 20-23.

Van Liew, Maria, 'Witness to War: Virginal Vicissitudes in VicenteAranda's Libertarias (1996)', Quarterly Review of Film and Video, 25 (2008), 230-240.

Vaz de Mello, Aníbal, Cristo, el Anarquista. Estudio sobre la personalidad y filosofía de Jesús de Nazaret (Editorial Claridad: Buenos Aires, I936).

Vincent, Mary, Catholicism in the Second Spanish Republic: religion and politics in Salamanca, I930-I936 (Oxford: Clarendon Press, I996).

Wallach, Jennifer Jensen, 'Building a bridge of words: The literary autobiography as historical source material', Biography, 3 (2006), 446-46I.

White, Luise, 'Telling more: lies, secrets, and history', History and Theory, 4 (2000), I I-22.

'Who can belong to CNT?' <http://www.cnt.es/en/who-can-belongcnt $>$ [accessed I4 February 20I 5].

Zubiaur Carreño, Francisco Javier, 'El Cine como fuente de la Historia', Memoria y civilización: anuario de historia de la Universidad de Navarra, 8 (2005), 205-2I9. 